\title{
Kong Zi on Good Governance ${ }^{1}$
}

Moses Aaron T. Angeles

K

ong $\mathrm{Zi}$ died carrying a disappointment in his heart. He searched in utter futility for a worthy individual who embodies his moral ideal to " the Sovereign, the one who will be regarded as the "Son of Heaven." He traveled far and wide tirelessly looking for a man who will cure the ills of the society, who will assume in himself the moral ideal, and end the strife that divides the warring states of China. Unfortunately, he never found such a man. He may be disappointed of how things have become, however, he did not despair ultimately. On the contrary, he expressed his hope and aspiration by leaving us with competent disciples who are more than willing to share what they have learned and committed into writing what they have heard and witnessed from the Master.

Kong Zi enjoys a universal appeal. He may have expressed his reflections as influenced by his own historical milieu, yet, his message is always fresh and not even an ounce of its luster vanished. Tonight, we do not simply celebrate the memory of the birth of China's eminent Master, but also try to reassess his reflections and how will it could be appropriated in our own situation. It cannot be denied that as a nation we are torn apart by a government ravaged by endless political rivalries. And because of this, we Filipinos lose our sense of what good governance is all about. We cannot anymore distinguish what is right and wrong, what is acceptable or not, what is good or bad, because we lose tract of a moral ideal. It is my hope this evening that we once again revive our idealism with Kong $\mathrm{Zi}$ as our guide.

This paper will delve into the problem of Good Governance in the light of Kong $\mathrm{Zi}$. What makes up a Just State? What are the elements that constitute a prosperous Kingdom? What principles of Confucianism can we employ to achieve a just and humane society? These are the primary questions that we will try to investigate as we go along. The paper will be thus divided into three essential parts: The Notion of $L i$ and the Sovereign, The Confucian Moral Ideal, and lastly, The Great Commonwealth.

1 This paper was delivered at the $18^{\text {th }}$ Annual Confucian Night, with the theme "Confucianism and its Relevance to Filipino Thoughts," held at the Jumbo Kingdom Floating Restaurant, Manila, September 28, 2007. 


\section{KONG ZI}

\section{The Notion of $L i$ and the Sovereign}

The Confucian notion of $L i$ lies at the intersection of politics and education. It is indeed a marvelous combination of education, self-cultivation, training, discipline, restraint, authority, and even legitimacy. On the educative side, we can infer that $L i$ is a behavioral norm that operates by being internalized by the person, so that in effect, it becomes part of his/her own being. The Master affirms this when he said in The Great Learning: "The cultivation of the person depends on rectifying the mind."2 Proficiency in acting according to $L i$ or Ritual Propriety ${ }^{3}$ is something that is learned and acquired through practice and continued repetition. The author thinks that it is captured by the notion of "discipline." We all know that Kong $\mathrm{Zi}$ once defined Ren as "to discipline (oneself) within the rules of proper human relations." 4 This shows, at least, that $L i$ and "discipline" are closely related to each other and thus significant for the cultivation of oneself.

On the contrary, $L i$ is corrupted or violated once its performance becomes routinary and mechanical. For the Confucian therefore learning is to discipline oneself according to $L i$ and it becomes an act that flows spontaneously in a ritually proper manner. Not only that, it is at once a process of learning to become human. Tu Wei-Ming, a scholar of Confucianism, himself affirms this when he states: "In the Confucian context it is inconceivable that one can become truly human without going through the process of ritualization." 5 This indeed is summarized in the beginning statement of The Great Learning. The Master said: "Things have their roots and branches. Affairs have their end and their beginning. To know what is first and what is last will lead to what is taught in the Great Learning." 6

On the Political side, $L i$ is vitally concerned with the notion of restraining the government. Observance of the prescriptions of $L i$ was of the utmost importance for each ruler. Because their political authority and legitimacy flows from correctly regulating their conducts according to $L i$, rulers had to acquire knowledge and this means that they have to receive advises from experts on the matter of $\mathrm{Li}$. The Three Stages of Ru Jia's education becomes all the more evident. The teacher of $\mathrm{L} i$ has to educate the sovereign to manifest the clear character of man. Second, to teach him in loving the people, and thirdly, that he should abide to the highest good. These are the elements that constitute a Confucian education that rears a character worthy of erudition.

2 The Great Learning, VII: 1. I used the translation of James Legge, in The Chinese Classics, with a Translation, Critical and Exegetical Notes, Prolegomena, and Copious Indexes (Hongkong: Hongkong University Press, 1970).

3 This translation of $\mathrm{Li}$ is based from Tu Wei-Ming's article "Process of Humanization," in Philosophy East and West, 22:2 (1972), 179-195.

${ }^{4}$ Lun Yu, XII: 1.

5 Tu Wei-Ming, op cit., 187.

${ }^{6}$ The Great Learning, I: 3. 
In The Great Learning, the Master was very emphatic that a just and tranquil state is only possible through the cultivation of one's virtues:

The ancients who wished to illustrate illustrious virtues throughout the kingdom, first ordered their own States. Wishing to order their States, they first regulate their families. Wishing to regulate their families, they cultivated their persons. Wishing to cultivate their persons, they first rectified their hearts. Wishing to rectify their hearts, they first sought to be sincere in their thoughts. Wishing to be sincere with their thoughts, they first extended to the utmost of their knowledge. Such extension of knowledge lay in the investigation of things. ${ }^{7}$

The Master continues:

Things being investigated, knowledge becomes complete. Their knowledge being complete, their thoughts were sincere. Their thoughts being sincere, their hearts were rectified. Their hearts being rectified, their person were cultivated. Their person being cultivated, their families were regulated. Their families being regulated, their States were rightly governed. Their States being rightly governed, the whole kingdom was made tranquil and happy. ${ }^{8}$

For sure, the disciples and followers of Kong $\mathrm{Zi}$ make it certain that the ruler, to become worthy of his position, knew that he had to be disciplined by $L i$ before he could claim authority to rule over others. The Sinologist Alfredo $\mathrm{Co}$, in commenting on the Virtuous Government, remarks: "Politics must be subordinated to morals. Kong $\mathrm{Zi}$ argued that the destiny of man is the attainment of happiness, and if that happiness is marked by social harmony, prosperity and peace, then only a morally righteous man could lead the society to such a noble end."

\section{The Confucian Moral Ideal: Teach the Virtue of Ren!}

Kong Zi's moral ideal emphasizes moral self-cultivation, the formation of one's character, and personal growth. Indeed, Confucianism sets the highest regard on self-restraint, the inner life, the nourishment or incubation of one's virtues, and the mastery and subordination of natural desires and selfish interests to higher moral demands. The Master asks: “Don't you realize that

${ }^{7}$ Ibid., I: 4.

8 Ibid., I: 5.

${ }^{9}$ Alfredo Co, Philosopby of Ancient China: The Blooming of a Hundred Flowers (Manila: UST Press, 1992), 115. 


\section{KONG ZI}

humanity comes from inside a person, and not from other people?"10 Ren, which is translated here as humanity, is the greatest virtue, and to realize it, one has to overcome the self. Overcoming the self necessarily involves recognizing the distinction between "what is fitting" and "what is profitable." "The Master said: 'The noble human being' is well acquainted with doing what is fitting, the 'mean spirited person' is well acquainted with how much money can he make." 11 This is quite common in case of quarrels and litigations. It cannot be denied that both parties are most of the times motivated with what is profitable, with how much money can he make, rather than what is moral or what is fitting. From the perspective of Kong $\mathrm{Zi}$, moral law requires one to live in harmony with other human beings surrounding the self.

Furthermore, in case of potential conflicts with others, the correct attitude would be that of self-scrutiny, that is, to examine oneself to see what one has done wrong and what failing one should be responsible for. Instead of asserting one's interests, there must be a polite yielding and giving concessions to others. This selfless act constitutes Kong Zi's Golden Mean and the Master seems to be hopeless when he said: Putting yourself is a state of steady equilibrium fills you with moral power. And that's what we are all striving for, isn't it? Though for a long time it has been rare to find this practice among the people."12

The duty of the true Confucian scholar is, therefore, to teach the people the virtues and the moral law, so that they would understand what is exemplary and what is shameful. The Master himself was very adamant in his imperative:

Lead the people with governmental regulations and beat them into line with punishments, and they will try to avoid wrong-doing so as to avoid the punishments, but they will have no sense of honor or shame. Lead them with moral power and discipline them within the rules of proper human relations and they will possess a sense of honor and shame. ${ }^{13}$

\section{The Great Commonwealth}

The construction of a harmonious social order is one of the greatest Confucian ideals. This is the famous vision of Da Tung, which is translated as The Great Commonwealth:

When the Great Way prevailed, every person was a part of public society, and public society belonged to everyone. The virtuous and the able were chosen for

\footnotetext{
${ }^{10}$ Lun Yu, XII: 1.

${ }^{11} \mathrm{Ibid} ., \mathrm{IV}: 16$.

12 Ibid., VI: 27.

13 Ibid., II: 3.
} 
public office. Fidelity and friendliness were valued by all. People not only loved their own parents and children, but loved the parents and children of others as well. The elderly lived their years in happiness; able-bodied adults were usefully employed, children were reared properly. Widowers, widows, and orphans, the childless aged, the crippled and the ailing were cared for. All men shared their social responsibilities and respective roles. Natural resources were fully used to benefit all, and were not appropriated for selfish ends. People wanted to contribute their strength and ability to society for public gain. Trickery and intrigues could not occur in such a society. Robbery, larceny, and other crimes all disappeared. Gates and doors were not locked; no one ever thought of stealing. This was the age of the great commonwealth of peace and prosperity. ${ }^{14}$

Harmony is the fundamental theme of the Great Commonwealth, and, according to Confucian perspective, harmony is an unqualified good, and Ritual Propriety $(L i)$ provides the means to this great end. According to the Lun Yu:

Scholar Yu said, 'In practicing the rules of proper human relations, a natural sense of effortless harmony is to be prized. The beauty of the proper way prescribed by the ancient kings consists in this sense of effortless harmony. We should act in accordance with these ways in all things great and small, but that is not enough. For when the people try to achieve effortless harmony without discipline within the rules of proper human relations, they become merely facile. ${ }^{15}$

Harmony in the society is thus highly regarded. In case of disputes among contending parties, Kong $\mathrm{Zi}$ offers a kind of governance that mediates any form of dispute and search for a solution which is agreeable and voluntarily accepted by the disputants. The objective of the Confucian is to resolve the issue by the employment of persuasion and education to make the parties rethink their original propositions. The ultimate aim therefore is to resolve personal issues and hence the restoration of personal harmony and solidarity that has been temporarily breached by conflict. Self-Cultivation is very necessary to attain this. The Master teaches: "Virtue is the root; wealth is

${ }^{14}$ This translation was taken from Alfredo Co, op cit., 116. The original text is in the opening portion of an Essay on the "Evolution of Rites" ( $\mathrm{Li}$ Y un ) in the Book of Rites (Li Ji), one of the great Confucian classics.

${ }^{15}$ Lun Yu, I: 12. 
the result."16 But he is quick to remind us: "In a State, gain is not to be considered prosperity, but its prosperity will be found in righteousness." 17

\section{Concluding Remarks}

The Great Commonwealth can only be therefore attained if one is to comport himself to $L i$ and to authentically manifest it in the domain of Ren. Kong Zi imparted invaluable teachings that lead to Good Governance, and we can say that it was his way of challenging us to set into execution what we have just learned. "To know the good is to do it" as they say, and Kong Zi will certainly nod in affirmation that true wisdom consists in the rectitude of with what we are doing and with what we are acting upon. Indeed, to acquire the skill in the investigation of things, to extend one's knowledge, sincerity in the will, the rectification of the mind, the cultivation of personal life, the regulation of the family, national order, and thus World Peace, these are the Eight Steps in the articulation of the Confucian Ren and these will certainly lead us to the Great Commonwealth.

The path towards the Great Commonwealth really depends on how we will conduct our journey. The road may be smooth if there is authenticity in our actions or it can also be rugged if we still cling to our selfish desires. The choice is ours.

Department of Social Sciences and Humanities, San Beda College, Philippines

\section{References}

Chang Ch'i-Yun, Confucianism: A Modern Interpretation (Taipei: China Academy Hwa Kang Press, 1980).

Cheng Tien-His, China Moulded by Confucius: The Chinese Way in Western Light (London: Stevens, 1946).

Co, Alfredo P., Philosophy of Ancient China: The Blooming of a Hundred Flowers (Manila: University of Santo Tomas Press, 1992).

Confucius, The Sayings of Confucius. Singapore: Graham Brash, 1983).

De Bary, Wm., Theodore and Tu Weiming, eds., Confucianism and Human Rights (New York: Columbia University Press, 1997).

De Bary, Wm., Theodore, Wing Tsit Chun, and Burton Watson, Sources of Chinese Traditions (New York: Columbia University Press, 1960).

Fung Yu-Lan, A History of Chinese Philosopby (Princeton: Princeton University Press, 1952).

Kong Zi, The Analects, trans. by D.C. Law (London: Penguin Books, 1979).

The Chinese Classics, with a Translation, Critical and Exegetical Notes, Prolegomena, and Copious Indexes, trans. by James Legge (Hongkong: Hongkong University Press, 1970).

16 The Great Learning, X: 7.

17 The Great Learning, X: 23. 
Tu Wei-Ming, "Li as Process of Humanization," in Philosophy East and West, 22:2 (1972), 179-195.

Wing-Tsit Chan, Sourcebook in Chinese Philosophy (New Jersey: Princeton University Press, 1961).

Wright, Arthur, Confucianism and Chinese Civilization (New York: Athenaeum, 1964).

Xunwu Chen, Being and Authenticity (Amsterdam: Rodopi, 2004).

Zhang Dainian, Key Concepts in Chinese Philosophy, trans. by Edmund Ryden (New Haven: Yale University Press, 2002). 